\title{
The Characteristics of Concept Maps Developed by the Secondary Schools and University Students
}

\author{
$1^{\text {st }}$ Ardian Anjar Pangestuti \\ Biology Education Studies Program \\ IKIP Budi Utomo Malang \\ Malang, Indonesia \\ co-author: \\ ardianpangestuti@gmail.com
}

\author{
$2^{\text {nd }}$ Siti Zubaidah \\ Biology Department Universitas Negeri \\ Malang, \\ Malang, Indonesia \\ siti.zubaidah.fmipa@um.ac.id
}

\begin{abstract}
A concept maps is one of the teacher's tools to measure students' prior knowledge, encourage them to perform meaningful learning and to increase their achievement. It also helps students to overcome difficulties in understanding a concept, empower their critical, creative and metacognitive thinking skills. Besides, it can serve as an evaluation tool in learning, and an early warning to detect students' misconceptions. The purpose of this study is to identify the characteristics of concept maps arranged by the junior high school, senior high school, and university students. This survey research was conducted to investigate the completeness of the students' concept maps, the types of the concept maps, and the students' misconceptions. Research participants consisted of 21 junior high school students, 19 senior high school students, and 35 university students. The results indicate that $98.7 \%$ of concept maps developed by the students did not have complete elements while the rest did. There were $90.7 \%$ of the concept maps were categorized into the Mixed type; $6.6 \%$ were Hub/Spokes, and $2.7 \%$ were Tree. Besides, $70.67 \%$ of the students' concept maps contained misconceptions.
\end{abstract}

Keywords-Characteristics, Concept Map, High School, Higher Education

\section{INTRODUCTION}

Teachers in the classroom have used concept mapping since a long time ago. It has been proved by several studies which reported on the effectiveness of concept mapping in improving students' competencies. Another promising proof is that many textbooks attach concept maps in the beginning or at the end of the book part. Concept mapping is a method of visualizing the structure of knowledge $[1,2]$. It constitutes a means to organize and evaluate students' achievement, it is characterized by circles or boxes or other forms containing concepts that are connected by lines [3]. The concept mapping as a technique used to understand the relationship between ideas by linking them with a visual map [4]. It is, thus, refers to a schematic diagram which is arranged radial (that resembles a web), with the central idea put in the middle of the map or on the top to be managed hierarchically [5].

Concept mapping offers numerous benefits. Concept mapping can be used to measure students' basic competence [6]. In addition to that, it helps students connect new information with their existing knowledge so that learning can be more meaningful and as a result, students' achievement can be improved [2,3,7,8]. Another advantage of concept mapping is that it assists students to deal with difficulties in understanding concepts and the relationship between them $[6,8,9,10]$. Concept mapping can also be used to improve students' critical thinking skills since it allows the students to think about the correlation between science concepts. The students are given an opportunity to organize ideas, visualize the relationship systematically, and also reflect on their understanding [2,11]. Furthermore, concept mapping is able to empower students' creative thinking skills [3,12]. It also improves students' metacognitive ability $[5,13,14]$. A concept map is normally used as an effective evaluation tool to detect students' misconceptions $[3,9,15$ 18]. Additionally, it is useful to organize and investigate students' basic concepts, knowledge, and understanding $[3,13,17,19]$. Concept mapping has been proved to be able to ease the learning process [15,20]. It describes the new knowledge acquired by students [6]. It shows how students organize, connect, and synthesize information [11]. Not to mention, a concept map can be used to examine learning materials scopes. It, therefore, serves as an assistant to help teachers memorize and design the materials [7]. The last benefits of a concept map are to facilitate students to plan and prepare the materials to be learned in the classroom [2]. By constructing concept maps students are expected to know the materials to be studied and understand all they had learned.

As a tool, a concept map is built from some components. A concept map is made of concepts, proposition, hierarchy, cross-links, and examples [21]. Followings are the explanation of each component [3]. The first component is the concept. The concept is written in a box or a circle or probably in another form. Every concept will be connected by a link that shows the relationship between them. On the link is added a linking word or phrase to make it more understandable to the readers. The second component is a proposition. Proposition describes a relationship between concepts (information). It consists of two or more concepts connected by a linking word or phrase which together form a meaningful statement. The third component is a hierarchy. Concept mapping is generally pictured in a hierarchical model. It means that the concepts written on the map are organized hierarchically from the most general one at the top 
to the most specific on the bottom. The fourth component is the cross-links. These links connect the concepts which are put in different segments or domains on the map. Therefore, cross-links indicate the connection between concepts on a domain of knowledge and concepts on another domain of knowledge. The last component is the examples. A good concept map should be equipped with examples to clarify the concepts.

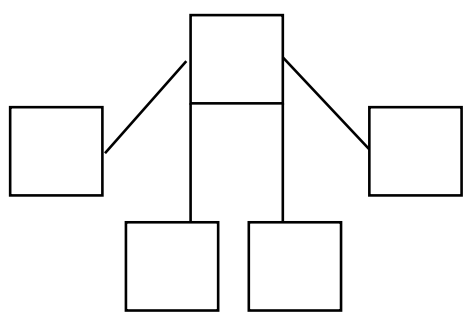

(a)

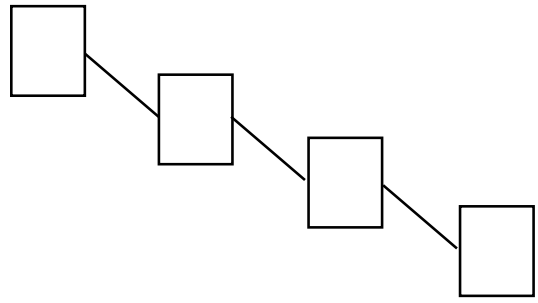

(b)

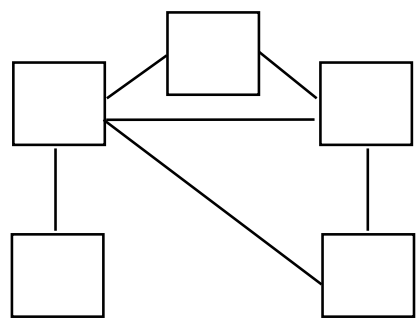

(c)

Fig. 1. Various Types of Concept Maps: (a) spoke, (b) chain, (c) net (Kinchin, 2000)

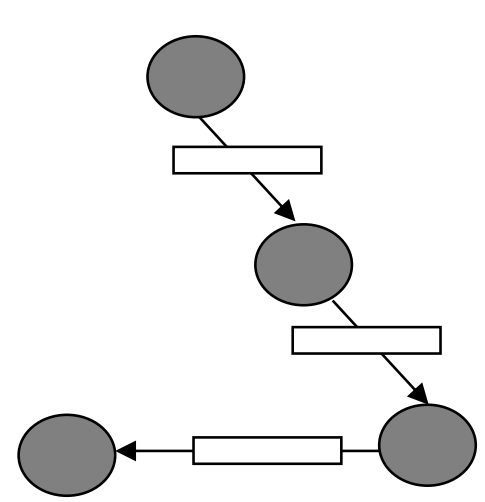

Linear

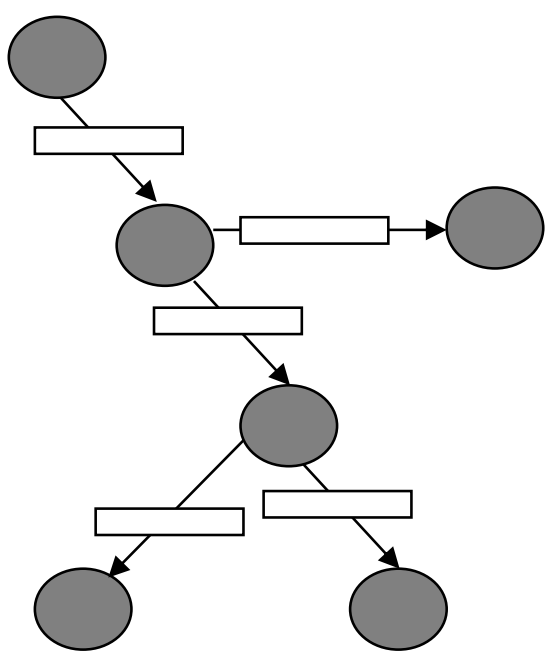

Tree

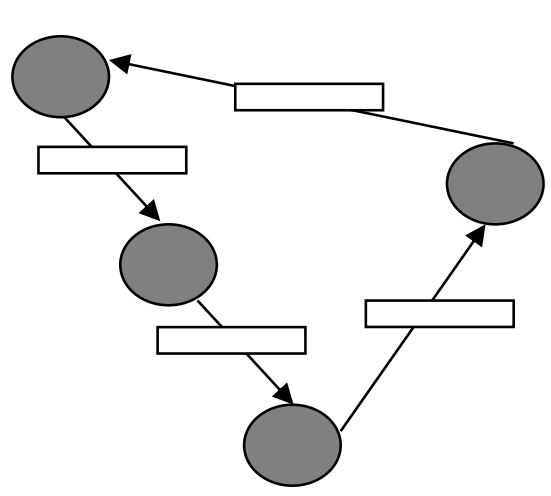

Circular

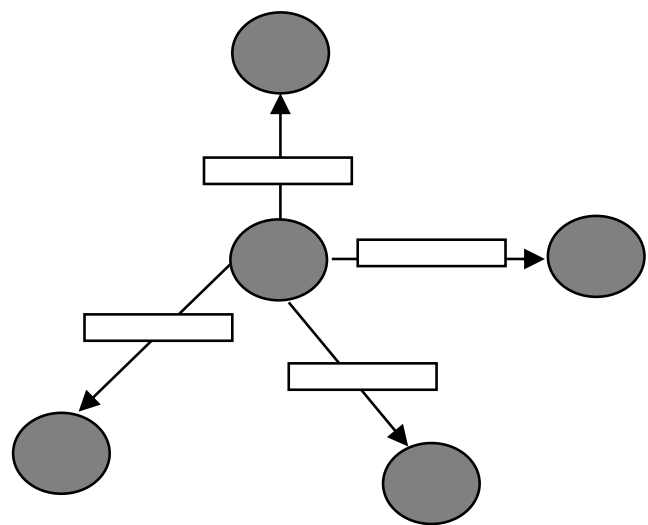

Hub/Spokes

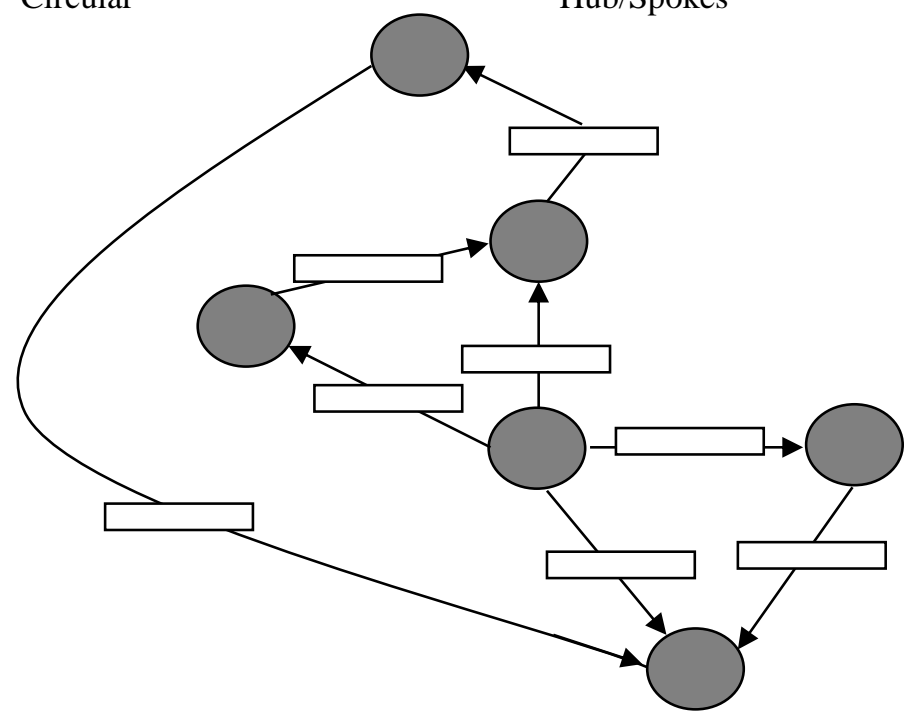

Network/Net

\section{Information}

Concept

Linking Phrase

Fig. 2. Various Types of Concept Maps (Vanides et al., 2005) 
There are three concept maps. They are spoke, chain, and net [22]. A spoke concept map resembles trellis. It comprises one level with concepts arranged downwards and sideways from more general concepts to more specific ones. The connection between the concepts on this map is effortless. The second type of the concept map is the chain. As it says, it appears like chains. This concept map consists of some levels on which concepts are organized straight downwards from the most general to the most specific ones. No branches can be found on the map. The third concept map is the net. The net consists of some hierarchies. Similar to the previous two concept maps, the concepts are organized downwards from the most general to the most specific ones. The difference, however, is found on the branch. Every level on the net has branches. That is why this concept map is most famous for its complexity. The three types of concept maps are portrayed in Fig. 1.

On the other hand, there are five categories of concept maps; they are Linear, Circular, Hub Spokes, Tree and Network/Net [11]. The first type is the linear concept map. At a glance, this concept map looks similar to the chain on which concepts are organized from the most general to the specific ones. What makes them different is that on the chain, the last concept is deflected to the left. Second is the circular concept map. In essence, this concept map has a circular form. The concepts are organized like a chain, but a linking word or phrase must be added to the last concept to connect it with the central concept or the concept that has been written for the first time. The third type is the hub/spokes. According to its name, the concepts on this map are written like a web. The central concept will be put in the middle and more specific concepts are written surrounding the central concept. Fourth is the tree. This concept map is similar to the linear concept map. The difference is that this concept map has branches. Fifth is the network/net. This concept map resembles the net suggested by Kinchin (2000). The five concept maps are described in Fig. 2.

A concept map can serve as an evaluation tool in learning. It also can help detect students' misunderstanding of a concept. Students' misconceptions refer to the condition where students develop a concept which is contradictory to the basic science concept or the concept that has been agreed upon among the experts. The misconceptions occur as someone misinterprets an idea, object, or event [23]. There are five categories of misconceptions, 1) preconceived notions; 2) non-scientific beliefs; 3) conceptual misunderstandings; 4) factual misconceptions; and 5) vernacular misconceptions [24,25].

This study aimed to investigate the characteristics of concept maps developed by the secondary and university students. By examining the characteristics of the students' concept maps, this study was going to reveal some important things including the completeness of the concept maps components, the types of concept maps used by the students, and the misconceptions found among the students.

\section{METHODS}

\section{Method}

This research was conducted from 6 July 2017 - 31 July 2017

\section{Research Subjects}

This research involved a group of junior high school students, a group of senior high school students, and some university students. The first group consisted of 21 students from seventh grade (VII B) of Public Junior High School No 1 in Tanjung Bunga Flores Timur. They were asked to draw a concept map related to the ecosystem and the relationship between the ecosystem and its components (Basic Competence 7.1). The next participants were 19 tenth graders (X MIA 2) from Public Senior High School No.2 Malang. The students were drawing a concept map in the biology classroom as to achieve Basic Competence 3.3 that was to analyze the characteristics, replication, and roles of virus in public health and Basic Competence 4.3 that was to present observation data on the characteristics, replication, and roles of virus in public health using various media. The last participants were the university students registered in the biology education program of IKIP Budi Utomo Malang in 2016. 35 students were enrolling in the general biology classroom. They were learning the structure and functions of the plant tissues at that moment.

\section{Research Procedure}

This research consisted of three consecutive stages. The first stage was to collect concept maps from the three groups of students (junior high school, senior high school, and university students). The analysis of the concept maps followed this stage. The concept maps were evaluated regarding the completeness of their components including concepts, proportions, hierarchy, cross-links, and examples. The concept maps were then categorized based on three types of the maps, which include speaking, chain, and net ${ }^{22)}$ and based on five types of the map, which consist of the tree, linear, circular, hub spokes, and network/net ${ }^{11)}$. The last step was to identify students' misconceptions.

\section{RESULTS AND DISCUSSION}

\section{The Completeness of the Concept Maps Components}

Research findings suggest that 74 or $98.7 \%$ of the students' concept maps were not complete concerning the components included while only 1 or $1.3 \%$ of the maps contained all the components. The results of data analysis on the concept maps completeness are explained as follows.

In general, almost all of the junior high school students drew incomplete concept maps. So did the senior high school students. On the other hand, one student or $2.9 \%$ of the participants from the university drew a complete map while 34 or $97.1 \%$ of the university students' concepts maps were also incomplete.

The main component of the concept map is the concept. All the concept maps generated by the junior and senior high school students contained the concept. Likewise, the university students' concept maps also included this component. The second component is a proposition. There were 8 or $38.01 \%$ of the junior high school students' maps 
contained proposition. However, there were only 7 or $36.84 \%$ of the concept maps generated by the senior high school's students contained proposition. Meanwhile, 21 of $60 \%$ of the university students' concept maps were equipped with a proposition.

A proposition indicates a relationship between concepts [3]. Based on the statement, it can be concluded that students who can write a proposition in their concept maps are the students who are able to find the connection between concepts. On the contrary, students who cannot include a proposition into their concept maps are not yet able to show the connection between concepts. It is difficult for the readers to read concept maps without a proposition because they cannot see the connection between the concepts (information) written on the maps.

Concerning the hierarchy, all the concept maps organized by the junior high school students consisted of four levels. There were 12 or $63.16 \%$ of the senior high school students' maps organized on one level; 6 or $31.58 \%$ organized on two levels; and 1 or $5.26 \%$ organized on three levels. Meanwhile, there were 4 or $14.28 \%$ of the university students' maps consisted of 2 levels; 13 or $37.14 \%$ consisted of 3 levels; 9 or $25.71 \%$ consisted of 4 levels; 2 or $5.71 \%$ consisted of 6 levels; 1 or $2.86 \%$ consisted of 1 level and 5 levels; and 4 or $11.44 \%$ consisted of ambiguous hierarchy.

Concept maps should be drawn on a hierarchical model where the most inclusive or most general concept is put at the top, and the most specific one is put below it. ${ }^{3)}$ Therefore, it can be said that the concepts should be arranged from the most general, less general, and the most specific ones. According to the statement before, students who are able to organize their concept maps with high levels are considered able to identify the most general concepts to the most specific ones on the maps.

The other component of the concept maps is cross-link which connects a concept to a particular domain of knowledge with another concept on another domain of knowledge [3]. Thus, it can be said that students who can identify cross-link in their maps are able to connect new information with their existing knowledge or experiences. Among the participants, there was only one concept map containing a cross-link. It indicates that the students had already experienced meaningful learning. Besides, students who are able to add a cross-link to the concept map are considered able to think creatively. In line with that, mentions two essential components in concept maps that can improve students' creative thinking skills; they are a hierarchical structure (students' ability to draw a good concept map) and the ability to identify a new cross-link between concepts [3].

The last component of concepts maps is the examples. Examples did not support all concept maps organized by the junior high school students. However, there were 11 or $57.89 \%$ of the senior high school students' maps provided examples, and there was only 1 or $2.86 \%$ of the university students' maps contained examples.

\section{The Types of Concept Maps}

The results of the data analysis show percentages of each concept map described as follows. There were $68(90.7 \%)$ concept maps were categorized into mapping types suggested by Kinchin (2000) and Yin (2005); 5 (6.6\%) maps were Hub/Spokes, and $2(2.7 \%)$ maps were Tree. Followings are the results of data analysis related to the types of concept maps. All the concept maps drawn by the junior high school students and the university students could not be categorized into types of concept maps suggested by Kinchin (2000) and Yin (2005). However, among the senior high school students' concept maps, there were $5(26.5 \%)$ maps were Hub/Spokes, $2(10.5 \%)$ were Tree. Meanwhile, the rest $(63.2 \%$ of the maps) had a similar organization to the ones arranged by the junior high school and university students.

As mentioned earlier, $90.7 \%$ of the students' concept maps did not belong to any types of concept maps suggested by Kinchin (2000) and Yin (2005). In fact, they combined Spoke and Net. Hierarchically, these concept maps consisted of some levels, and each level had developed concept branches. On this type of concept map, the concepts are organized downwards from more general concepts to the most specific ones. It means that the most general concept is put at the top and the more specific concept is put on one level below it.

On the Net concept map, adding the concepts will also add the number of the branches on every level [22]. It derives in the richness of the concept map structure. However, concepts reduction will not have any significant effect on the map structure.

A cross-link can be found on this type of map. The crosslink shows the connection between a concept on a domain of knowledge with another concept on another domain of knowledge. This concept map enables students to link what they are learning with what they have experienced. Thus, through the organization of this concept map, students are more likely to receive meaningful learning. A cross-link is one of the concept map components that can help promote students' creative thinking skills [3].

The new type of concept map which does not belong to either Kinchin (2000) or Yin's (2005) mapping categorization is called Mixed. Fig. 1 shows this type of concept map.

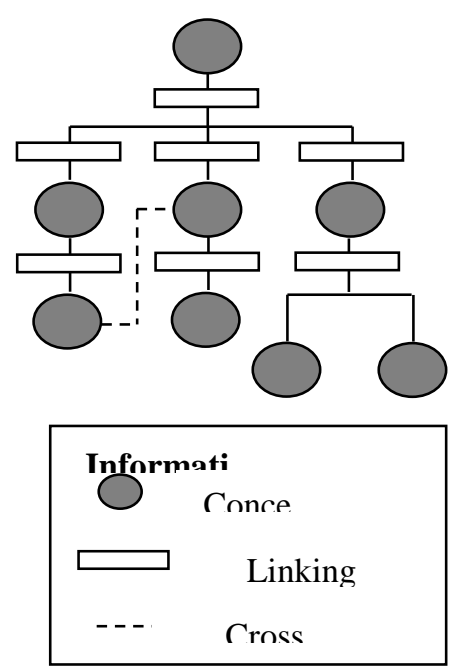

Fig. 3. Mixed Concept Map Found by Authors 


\section{Misconceptions}

The results of the research indicate that misconceptions were found in $53(70.67 \%)$ concept maps. It can be explained as follows. Misconceptions were found in 21 (100\%) concept maps developed by the junior high school students. Meanwhile, $10(52.63 \%)$ maps developed by the senior high school students contained misconceptions and $23(65.71 \%)$ maps developed by the university students indicated the existence of misconceptions.

There are seven categories of misconceptions mentioned earlier. This categorization was set as the standard to evaluate the students' concept maps. There were, thus, two categories of misconceptions in the students' maps. The first category referred to conceptual misunderstanding. It resulted from the students' inability to organize their knowledge on their thinking framework [24,25].

For instance, the junior high school students wrote: 1) the ecosystem consists of individuals, population, community, and ecosystem; 2) in addition to the community, a biome constitutes a unit which forms the ecosystem; 3) food chains will result in food pyramids and energy flows. The correct concepts are: 1) individuals, populations, and communities are the organizational levels in ecosystems ranging from the smallest to the largest; 2) some similar individuals that gather in the same place and within a specified period of time will form a population, a group of several populations that live together in a particular place will form a community, the community and environment have a reciprocal relationship to form an ecosystem; 3) a food chain shows a linear schematic picture of how living creatures get food, a food pyramid shows the ratio of biomass and energy delivered from producer organisms to tertiary consumers at the top in an ecosystem, meanwhile an energy flow indicates an energy transformation from the sun to producer organisms and is forwarded to consumer I, II, III, and ends in decomposers.

The examples of misconceptions found among the senior high school students are: 1) virus is categorized into two, living virus and dead virus; 2) the lysis stage of the lytic cycle occurs when a new virus is ready to attack other bacteria; 3 ) one characteristic of the lysogenic cycle is that cell fusion ends it; 4) one of the positive roles of virus is to generate an antioxidant; 5) virus is made of head, capsid (DNA/RNA), tail fiber, and tail plate; and 6) a lytic cycle consists of the injection, synthesis, assembly, lysis, and phage stages.

The right concepts are actually: 1) virus is categorized based on nucleic acids which construct its genome. As a result, there are two categories of virus namely DNA and RNA virus; 2) the process that occurs during the lysis stage of the lytic cycle is virus-producing an enzyme which functions to destroy cell wall of bacteria; this leads to broken cell wall, and the virus finally released; 3) one characteristic of the lysogenic cycle is the process of virus genome replication which is executed without having to destroy the host cell; 4) one of the positive roles of virus is to help produce vaccine and insulin; 5) virus has various sizes and forms, but primarily a virus is made of nucleic acid (DNA or RNA) which is wrapped by a protein layer (capsid) and sometimes covered by viral envelopes; 6) a lytic cycle consists of the injection, synthesis, assembly, and lysis stages.

The examples of statements made by the university students which indicate the misconceptions are: 1) a stem functions to transport nutrients to all parts of the plant and it helps pollination; 2) dicotyledonous plants function to form the skin while the outside forms wood because of the cambium activity; 3) primary meristem and secondary meristem are organelles; 4) the free tissue is an adult tissue; 5 ) the vascular tissue supports some parts of the plant on the ground and provide strength and balance for the plant; 6) phloem has function to transport glucose and amino acid from the leaves and all cells; and many others.

However, the actual concepts are explained as follows. First, a stem functions to support some parts of the plants which appear on the ground such as leaves, flowers, and fruits; its branches will extend the assimilation and place the plant parts in a beneficial position; a place to preserve food; and a vessel to transport water, nutrients, and assimilation results from the bottom to the top. Second, cambium in dicotyledon plants is found between xylem and phloem. Cambium is a tissue which actively forms new cells either to outside or inside. New cells which grow to the inside will be differentiated into secondary xylem meanwhile new cells which grow to the outside will be differentiated into the secondary phloem. It is a result of the improved size of the dicotyledonous plant's cylinder. Third, primary meristem and secondary meristem are categorized into young tissues. Fourth, the adult tissues consist of epidermal tissue, parenchymal tissue, support tissue, carrier tissue, and cork tissue. Fifth, the vascular tissue is a tissue that functions to transport water, nutrients, and assimilation results. It consists of xylem and phloem tissues. Sixth, phloem has a function to transport photosynthesis results to all parts of the plant which need food.

The second category of students' misconception is a vernacular misconception. This misconception occurs due to the inappropriate use of vocabulary items or terms in describing scientific concepts. ${ }^{24,25)}$ Vernacular misconceptions found among the junior high school students are that they used 1) "components" instead of "consumers"; 2) "donation" instead of "population", and 3) "ambiotic" instead of "abiotic". In addition to that, the senior high school students mentioned "antioxin" to replace "antitoxin" and the university students changed "felem" into "falem".

Regarding some scientific definitions, the university students mentioned that ecodermic, endodermic, and periderm distinguished cork tissue. This concept is wrong because cork tissue consists of exodermic, endodermic, and periderm. Another misconception is that the university students said that plants organs comprise flowers, root plants, stem plants, and leaf plants instead of saying root, stem, leaves, flowers, and seeds. In addition to that, they added and many others to collenchyma and sclerenchyma as the supportive connective tissues.

In this study, the students' concept map is used to know the characteristic of concept maps arranged by the students and to detect the misconceptions found among the students. One of the results of this study shows that several 
misconceptions are found in both Secondary Schools and University Students. Misconceptions should be of particular concern to teachers, because misconceptions may affect the correctness of concepts understood by students. Therefore, the teacher should pay careful attention to the students' concept maps, because concept maps are students' unique and valuable piece of work. By doing so, the teacher can evaluate and monitor how the students construct an understanding and as a result help them improve their competencies, and fix their misconceptions.

\section{CONCLUSION}

Research findings suggest that:

1. $68(90.7 \%)$ concept maps were categorized Mixed concept map, $5(6.6 \%)$ maps were categorized as Hub/Spokes, and 2 (2.7\%) were Tree. A mixed concept map is a new type of concept map found in this research and quite dominant among the students' choices.

2. $74(98.7 \%)$ concept maps organized by the three groups of students (junior high school, senior high school, and university students) were incomplete regarding concept map components, and only $1(1.3 \%)$ map included all the components.

3. $53(70.67 \%)$ concept maps organized by the three groups of students contained misconceptions. These misconceptions are categorized into concepts misconceptions and language misconceptions.

\section{REFERENCES}

[1] Asan, A., "Concept Mapping in Science Class: A Case Study of fifth-grade students", Technology \& Society, vol. 10(1), pp. 186-195, 2007.

[2] Mahanal, S., Zubaidah, S., Bahri, A., Dinnurriya, S., "Improving Students' Critical Thinking Skills Through Remap NHT in Biology Classroom”, AsiaPacific Forum on Science Learning and Teaching, vol. 17(2), pp. 1-19, 2016.

[3] Novak, J. D., Canas, A. J., "The Theory Underlying Concept Maps and How to Construct and Use Them", Technical Report IHMC CmapTools, Florida Institute for Human and Machine Cognition, 2006-01 Rev 01-2008.

[4] Johnston, C., "Concept Mapping For Students in the Faculty of Business and Economics Teaching and Learning Unit, Faculty of Business and Economics at the University of Melbourne”, (Online),http://fbe.unimelb.edu.au/data/assets/pdf f ile/0005/659984/Concept mapping.pdf/0, 2010

[5] Llewellyn, D., Teaching High School Science through Inquiry and Argumentation. California: Corwin A SAGE Company, 2013.

[6] Hay, D., Kinchin, I., Baker, S. G., "Making Learning Visible: The Role of Concept Mapping in Higher Education", Studies in Higher Education, vol .33(3), pp. 259-311, June 2008.

[7] Meltzer, "The relationship between mathematics preparation and conceptual learning gains in physics: A possible "hidden variable" in diagnostic pretest scores", American Journal Physics, vol. 70(12), pp. 1259-1268, 2002.

[8] Daniela, C. C., Propescu, F. F, Ioan, P. A., Andrei, V., "Conceptual Maps and integrated Experiments for Teaching/ Learning Physics of Photonic Devices", Procedia-Social and Behavioral Sciences vol. 191, pp. 512-518, 2015.

[9] Edmondson, K. M. \& Smith, D. F., Concept map to Facilitate Veterinary Students' Understanding of Fluid and Electrolyte Disorders, Annual Meeting of the American Education Research Association. New York, 1996.

[10] Patrick, A. O., "Concept Mapping As a Study Skill: Effect on Student Achievement in Biology", International Journals of Education Science, vol. 3(1), pp. 49-57, 2011.

[11] Vanides, J., Yin, Y., Tomita, M., Primo, A. A. R., "Using Concept Maps in The Science Classroom", Science Scope, vol. 28(8), pp. 27-31, 2005.

[12]Zubaidah, S. Fuad, N., M., Mahanal, S., Suarsini, E., "Improving Creative Thinking Skills of Students through Differentiated Science Inquiry Integrated with Mind Map", Journal of Turkish Science Education, vol. 14(4), pp. 77-91, 2017.

[13] Novak, J. D, "Meaningful Learning: The Essential Factor for Conceptual Change in Limited or Inappropriate Propositional Hierarchies Leading to Empowerment of Learners", Wiley Periodicals, Inc. Sci-Ed., vol. 86, pp. 548-571, 2002.

[14] Corebima, A.D., Pembelajaran Biologi yang Memberdayakan Kemampuan Berpikir Siswa. Palangkaraya, 23 Agustus 2006.

[15] Novak, Y., Gowin, Learning How to Learn. Cambridge: Cambridge University Press, 1985.

[16] Trehan, D. M., The Impact of Concept Mapping as a Learning Tool on Student Perceptions of and Experiences with Introductory Statistics, Ph.D. Thesis, Kent State University, 2015.

[17] Waers, M. P., Concept Maps as a way to Improve Understanding and Organization of Concepts within a Subject, Master Thesis, Ohio University, 2015.

[18]Zubaidah, S. \& Pangestuti, A. A., Peta Konsep sebagai Alat Evaluasi pada Pembelajaran Biologi, National seminar proceeding on XIII Pendidikan Biologi FKIP UNS 2016, edited by A. D. Corebima. et al. (Universitas Sebelas Maret, Surakarta, Indonesia), pp. 164-168, 2016.

[19] Pangestuti, A. A., Mistianah, Corebima, A. D, Zubaidah, S., "Using Reading-Concept Map-Teams Games Tournament (Remap-TGT) to Improve Reading Interest of Tenth Grade Student of Laboratory Senior High School State University of Malang", American Journal of Educational Research, Vol. 3(2), pp. 250-254, 2015.

[20] McAleese, Ray, "The knowledge arena as an extension to the concept map: Reflection in action", Interactive Learning Environments, vol. 6(3), pp. 251-272, 1998. 
[21]Zubaidah, S., "Pemberdayaan Keterampilan Penemuan dalam Scientific Approach melalui Pembelajaran Berbasis Remap Coople", Prosiding Seminar Nasional XI Pendidikan Biologi FKIP UNS 2014, edited by Puguh Karyanto, et al. (Universitas Sebelas Maret, Surakarta, Indonesia), pp. 1000-1011, 2014

[22] Kinchin, I.M., "Using Concept Maps to Reveal Understanding: A Two-Tier Analysis", School Science Review, vol. 81, pp. 315-333, 2000.

[23] Thompson, F. \& Logue, S., An Exploration of Common Student Misconceptions in Science.
International Education Journal, vol. 7(4), pp. 553$559,(2006)$.

[24] National Research Council, Science teaching reconsidered: A handbook, Washington, DC: National Academy Press, 1997, pp.27-32.

[25] LeVaughn, Justin M., What's in A Gene: Undergraduates' Ideas and Misconceptions about Gene Function, Thesis and Dissertations, University of Kentucky, 2016. 